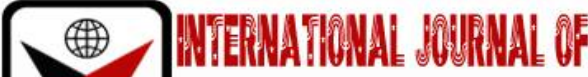

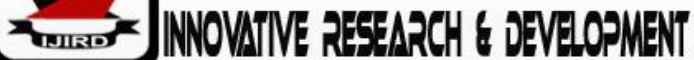

ISSN 2278-0211 (Online)

\section{Philosophy and Restructuring of Nigeria: An Afrocentric Perspective}

\author{
Dr. Innocent Ngangah \\ Senior Lecturer, Department of Philosophy, \\ Chukwuemeka Odumegwu Ojukwu University, Nigeria
}

\begin{abstract}
:
Nigeria is bedeviled with a political arrangement that is far removed from the cultural experience and inclination of its constituent nationalities. Before independence, there were two imperial ecosystems at play in the country: the external and the internal. While Nigeria's independence in 1960 politically removed the external chains, internal ethno-political domination continued thereafter to undermine the socio-cultural and political development of the country. This has created a state of anomie, mutual suspicion, cross-country violence, corruption and stasis. The paper paints an analytical picture of "internal disharmony" and "economic subversion", both of which combine to disorient the citizenry and frustrate the country's desire to reap durable political and economic capital from its enormous human and material resources. The paper calls for an afrocentric response to Nigeria's structural anomalies and the adoption of some tenets of traditional African political philosophy, notably its village-square representation and principle of consensual obligation. The paper recommends cultural and economic autonomy for Nigeria's distinct groups and regions in order to enhance the maximal release of their tethered developmental energies.
\end{abstract}

Keywords: Restructuring, Nigeria, domination, African philosophy, consensual obligation, political representation

\section{Introduction}

Although philosophy generally studies fundamental concepts such as reality, causality, existence and truth, our use of the term will be limited to its deployment as a system of thought in political and social organization. In particular, we will be examining how some vital aspects of African philosophy can be used as instruments of political engineering to restructure Nigeria and sustain its wellbeing, unity and stability as a nation state.

Whether consciously or unconsciously expressed, one philosophic principle or the other is behind any social, economic or political system. The way individuals or social groups understand the world (their philosophic orientation) often aggregates into the way a given society is organized. So, philosophy, in this sense, is the bedrock of any social organization. To alter a social or political system, therefore, the most fundamental thing to do is to alter the philosophical underpinnings of that system. Trying to restructure a social system without modifying its philosophical foundations is practically "absurd":

It is indeed absurd to talk about development or impose on a human race a civilization without reference to philosophy. Philosophy is a living subject which embraces all dialectical interpretations of life changes in society. It gives...understanding of reality by acting as a means to an end, through the interpretations of logical relations, ethical issues of categorical imperatives and methodological principles and concepts...Philosophy could be a genuine supporting tool...(for) proper restructuring of the polity... (Asike 2017)

This explains our recourse to political philosophy in the search for enduring restructuring and survival of Nigeria, a country which is at the moment more divided than it was at independence in 1960.

Nigeria has under-performed as a country on almost every index of development or stability. Within Nigeria, the ruling oligarchy and their minions have their own self-serving narrative that point to a glorious country (the "giant of Africa", "Africa's largest market") but scaled comparatively with other countries, even with other developing countries, Nigeria rates miserably low.

To mention only one of such indices, Nigeria's 2017 Human Development Index (HDI) is 0.532, "which put the country in the low human development category-positioning it at 157 out of 189 countries and territories" and bringing it "below the average of 0.537 for countries in Sub-Saharan Africa". (UNDP 2018) There are 46 countries in Sub-Sahara Africa, including ECOWAS, east/central African, and southern African countries. Nigeria's HDI ranking (and Nigeria is the world's $6^{\text {th }}$ and Africa's largest producer of crude oil) is below the average for these developing countries!

Since the HDI is an average measure of human development, based on the three dimensions of "a long and healthy life, access to knowledge and a decent standard of living" (UNDP), it masks some degrees of inequalities in a country. Hence, in 2010, the UNDP introduced the Inequality Human Development Index (IHDI) which "which takes into account inequality in all three dimensions of the HDI by 'discounting' each dimension's average value according to its level of 
inequality" (UNDP 2018). "As the inequality in a country increases," notes the UNDP, "the loss in human development also increases" (UNDP). Accordingly, Nigeria's IHDI for 2017 is 0.347, "a loss of 34.7percent due to inequality in the distribution of the HDI dimension indices" (UNDP), This is really sad when it is realized that "The average loss due to inequality for low HDI countries is 31.1 percent and for Sub-Saharan Africait is 30.8 percent" (UNDP). Nigeria's loss is greater than these two average losses.

Nigeria's losses in human development ranking have a lot to do with its perennial political instability. Studies have shown that there is a direct relationship between political stability and economic development, particularly in emerging market economies (EMEs), one of which Nigeria is. One of such studies opines that:

Political stability is important for business environments in EMEs, as it affects investor and consumer confidence, thus having a wider impact on the economy...rising political instability has undermined business environments...Changes in political stability, therefore, have implications for investment, consumption and economic growth... (Euromonitor 2019)

As the above information might indicate, Nigeria needs to undergo structural changes if its yearnings for political, social and economic stability, which has eluded it since 1960, would finally be realized.

\section{Background Information on Nigeria's Socio-Political Problems}

Some acquaintance with Nigeria's political history and behavior is necessary for the reader to appreciate and understand the philosophical dimension of this discourse, and this section will briefly serve that purpose. Nigeria, a country of over 250 ethnic groups and over 300 linguistic groups, got its independence from Britain in 1960. From 1960 to 1966, it practiced Westminster-style parliamentary democracy that enabled its constituent Northern, Eastern and Western regional governments to experience some measure of political and economic autonomy under a federal constitutional arrangement negotiated by all-Nigeria delegates during the country's pre-independence constitutional conferences.

The three regions (and a later-created Mid-West Region) were at peace with each other, as they enjoyed substantial political and economic autonomy. The 1960 and 1963 Constitutions granted the regions the following powers:

- Each region was politically autonomous: it had its own constitution, ambassadorial representative in the UK, its own separate coat of arms and motto. Besides, each regional government had residual power which made any matter not allocated to the federal government or the regions to become automatically a matter for regional jurisdiction.

- Each region was economically autonomous as the revenue allocation formula was based on derivation. The region retained and controlled $50 \%$ of its own resources while allocating to the federal government $50 \%$ of derived revenue.

- The concurrent list exercisable by the regional and central governments contained many items which further empowered the regions. The items under the Concurrent Legislative List of the 1960s' civil-rule era include arms and ammunitions, registration of business names, census, regulation of professions, and maintenance of public safety and public order. Others are commercial and industrial monopolies, statistics, combines and trusts, bankruptcy and insolvency, higher education, and industrial development.

The regions performed creditably in the areas of agriculture, education, telecommunications and basic infrastructural development. In the agricultural sector, cash-crop exports contributed $70 \%$ of Nigeria's total foreign exchange in 1963 and 66.4\% of GDP in 1965 (Izah 2008). At that time, more than 70\% of the Nigerian workforce was employed by the agricultural sector. There was healthy rivalry between the three regions, each of which built a university, established industrial corporations, and set up radio and television stations.

In 1966, Nigeria's political fortunes and potential for agro-industrial development was marred when the military terminated the country's nascent democracy and the regional governments (replacing them with 12 newly-created states), and enthroned military rule. The bloody nature of the 1966 coup provoked ethnic violence that ultimately plunged the country into civil war from 1967-1970. But for slightly over four years of civil rule between 1979 and 1983, the country remained under military rule till 1999 when civil rule was restored under a militarily-imposed 1999 Constitution that over-centralized power and put resource control in the hands of the federal government, as was the case throughout the military era. Corruption remains endemic even as the states accuse the federal government of undermining fiscal federalism. In 2017, Transparency International ranked Nigeria 148 least corrupt country out of 180 countries.

Today, Nigeria is seen by the average Nigerian as a nation in dire need of structural repair. As Asike (2017) put it, "lack of national integration...has been the cause of conflict in Nigeria. The ethnic relation in Nigeria is fragmented...It is a nation characterized with division, hatred and rancor". On why Nigeria is tottering as a country, Abutudu (2010) traces the problem to "the absence of a consensus on how the coexistence of the diverse peoples that make up the country should be managed." He notes that in spite of the fact that Nigeria has changed its constitution several times, she is yet to come up with "enduring constitutional provisions governing access to power, the distribution of power, the allocation of revenue, the units and levels of government, and so forth." What basically is the problem with Nigeria? Welson (2011):

Since Nigeria's independence in 1960, the country has continuously been confronted with among other issues, the problem of a weak and unjust social structure resulting in widespread social injustice. It is at the root of most of the crises and social malaise of the Nigerian society and is made more serious by the problems associated with ethnicity and arbitrariness by the state and government. Part of the resultant effects of this weak structure include unjust public institutions and social, ethnic, religious and political crises due mainly to a lack of social cohesion, political integration and an unfair principle of distribution of income, resources, goods and burdens in the society. All attempted palliatives by different administrations have all failed... (Welson 2011) 
Many prominent Nigerians believe the failure of the palliatives urgently signals the need to restructure Nigeria. This paper believes that what Nigeria needs is not another foreign constitutional model but the integration of indigenous African political practices that had worked for the nationalities that make up Nigeria in pre-colonial times. This paper will identify those highly recommendable and workable practices soon. Fortunately, all of them fundamentally fit into the mould of sound philosophical concepts aside from fulfilling the demands of African values and traditions. There is a role for political philosophy, universal and African, in working out a political framework for a durable, indigenously-inspired restructuring of Nigeria.

\section{Political Philosophy and Social Organization}

Since Plato's Republic (written around 380 BC) and Aristotle's Politics, political philosophy has influenced the way society and nations are organized. Other ancient political philosophers include Cicero, Confucius, St. Augustine (author of City of God and father of Scholasticism), St. Thomas Aquinas (author of Disputed Questions on Truth and father of Thomism) and the Islamic philosopher, Ibn Khaldun.

Political philosophy became generally secular during the Renaissance era. Outstanding works of the period include Niccolo Machiavelli's The Prince (published posthumously in 1532), Hugo Grotius' On the Law of War and Peace (1625), Thomas Hobbes' Leviathan (1651), John Locke's Second Treatise of Government (1629) and Jean-Jacques Rousseau's The Social Contract (1762) and Emmanuel Kant's The Metaphysics of Morals, Part 1 (1797). Many of the outstanding philosophers of the period discussed, among other things, the issue of natural rights and the need for the individual to surrender some of his natural rights to the state in order to achieve state control over the excesses of individuals. Celeste Friend's explanation of the core aspects of social contract doctrine is very insightful and worth this long quote:

The most basic covenant, the social pact, is the agreement to come together and form a people, a collectivity, which by definition is more than and different from a mere aggregation of individual interests and wills. This act, where individual persons become a people is "the real foundation of society" (59). Through the collective renunciation of the individual rights and freedom that one has in the State of Nature, and the transfer of these rights to the collective body, a new 'person', as it were, is formed. The sovereign is thus formed when free and equal persons come together and agree to create themselves anew as a single body, directed to the good of all considered together. So, just as individual wills are directed towards individual interests, the general will, once formed, is directed towards the common good, understood and agreed to collectively. (Friend 2019)

In the 20th century, Hegelian dialectics and Marxism became prominent. The Russian Revolution of 1917 and the establishment of the Soviet Union (founded on Marxist ideology) fueled the spread of Marxism and socialism not only in Europe but across the world (AHA 2019). Many events of the 20th century, including the granting of political independence to several African countries, have direct or indirect links to the ensuing Cold War that erupted for decades between the capitalist world (led by the United States) and the communist world (led by the USSR). Global fascination with Marxist ideology waned before the end of the $20^{\text {th }}$ century due largely to the collapse of and dismemberment of the Soviet Union. Whereas the whole of Eastern Europe was, for more than half a century, a bloc of communist countries, no country in that part is today communist. And with the exception of North Korea and mainland China, no country of the 21 st century tags itself with the communist nomenclature.

Interest in the issue of "original contract", emphasized in this review because of its direct bearing on the later part of our discussion, re-emerged towards the end of the $20^{\text {th }}$ century. John Rawls' A Theory of Justice (1971) espoused a Kantian dimension to the idea of a social contract that became notably influential. Of particular interest to our study here are the twin issues of implicit and explicit consent by all the parties to a social contract. A related concept is voluntarism, which holds that for a contract to be deemed valid, all parties to the contract should voluntarily accede to it explicitly or tacitly. Lysander Spooner, in his 1867 book, No Treason, wrote passionately in support of this concept. Below, as we conclude this section, is an introductory passage taken from his detailed argument:

If it be said that the consent of the most numerous party, in a nation, is sufficient to justify the establishment of their power over the less numerous party, it may be answered:

First. That two men have no more natural right to exercise any kind of authority over one, than one has to exercise the same authority over two. A man's natural rights are his own, against the whole world; and any infringement of them is equally a crime, whether committed by one man, or by millions; whether committed by one man, calling himself a robber, (or by any other name indicating his true character,) or by millions, calling themselves a government.

\section{African Traditional Political Systems}

We begin this segment with a brief review of literature published on the subject of African traditional political systems. Because Africa's political thought and practices were passed on from generation to generation by oral tradition, written documentation of Africa's traditional political systems is fairly recent. Some of the prominent publications include African Political Systems, a selection of anthropological papers published in 1940 and edited by Meyer Fortes and E. E. Evans-Pritchard. A more recent, and very outstanding study, is George Ayittey's Indigenous African Institutions which was first published in 1991. Guy Martin's African Political Thought (2012) is devoted to indigenous African political thought but has a fair representation of modern African political thought. This is an important book in the distinct and relatively new discipline of African ideology or African political thought. Another significant book is African Civilizations: An Archaeological Perspective written by Graham Connah and published in 2001.

These and other publications point to a robust history of political formations in pre-colonial African societies. Although there were no formal constitutions and codified laws, traditional African polities were based on traditional 
values and norms of Africans out of which emerged systems of political organization and power succession. Ayittey (2006) has observed that in terms of philosophical foundations:

The construction of a pre-colonial African society is not dissimilar to the constructions of Locke, Rousseau and especially in their presuppositions, to that of Grotius. These European legal philosophers recognised the fact that sovereignty resided in the generality of the people and....also that the ruler was ultimately bound by natural law to govern justly even in the absence of any specific undertaking on his part to that effect. This is the same in African societies, especially pre-colonial Africa, where the leader or chief leads at the pleasure and behest of the people...and must rule according to the dictates of the tradition of the land. (25)

Hence, principles of political philosophy of both African and universal relevance will guide our analysis of African traditional political systems we shall be discussing in this paper and the lessons derivable from them that may enrich the current debate on the need to restructure the Nigerian state.

There were two broad organisational structures of indigenous African political systems that were prevalent in pre-colonial times. Generally "based upon kinship, ancestry and survival" (Ayittey 29) and upon public rules of conflictresolution, pre-colonial African societies could be classified into two major groups, namely, "those that have 'centralised' / chiefly political systems...and those that have 'non-centralised'/chiefless political systems" (Ayittey 30). We speak of "systems" because a plurality of centralised and non-centralised political groupings, with peculiar expressions, existed. But just as today we can talk of the common elements of democratic countries, in spite of differences in democratic structures, we can as well itemize the general features of centralized African political systems and those of non-centralized African political formations of the pre-colonial era. This is to enable us appreciate the differences between these two broad political formations as well as identify features of political engineering common to both systems - positive attributes this paper believes Nigeria can adapt to make its constitution more inclusive, thereby laying the foundation for a more peaceful and durable political future.

African Political Systems contains the outcome of field research on pre-colonial African political formations. Edited by Fortes and Evans-Pritchard (1950), the book provides one of the first insights into the way traditional African States and stateless communities were politically organized. Subsequent research by African scholars, notably that of Ayittey (2006), while providing fresh insight into the subject matter, have broadened our understanding of the characteristics of Africa's state and stateless formations.

In summary, each of Africa's pre-colonial chiefly societies, such as "the Fanti of Ghana, Yoruba of Nigeria, Zulus and Pedi of South Africa, Bayankole of Uganda and Bemba of Zimbabwe", has the following features:

- Centralized authority and closely-controlled bureaucracy

- Government headed by a chief and local rulers appointed by him or recommended by village groups

- Council of elders who keep the ruler in check as well as provide him with bottom-up information

- Judicial system for the settlement of conflicts and disputes

- Pronounced political consciousness and a sense of state identity (Ayittey 2006)

Broadly speaking, each of Africa's pre-colonial stateless societies, such as "the Fanti of Ghana, Yoruba of Nigeria, Zulus and Pedi of South Africa, Bayankole of Uganda and Bemba of Zimbabwe" has the following features:

- Prevalent in homogenous cultures where the constituent families and villages are socially cohesive

- Non-centralized authority and a loose bureaucracy

- Governed by the Council of lineage heads / title-holders and the all-village Assembly

- Checks and balances provided by the balance of counter forces in the various strata of the society

- Conflicts and disputes resolved by extended family associations and kinsmen/neighbourhood groups

- (Ayittey 2006)

\section{Key Pre-Colonial Political Concepts Nigeria can Adapt to Re-engineer Its Polity}

In spite of the above differences, Africa's pre-colonial chiefly and chiefless political systems share some common tenets of social organization. These common political features, the adoption of which this analyst believes would resolve some of Nigeria's socio-political issues, are itemized and briefly-explained below.

\subsection{Political Autonomy}

According to historical records, most pre-colonial African societies, chiefly or stateless, were politically autonomous. (Fortes and Evans-Pritchard, 1950; Ayittey, 2006; Shumway, 2013). True federalism, similar to what obtained in the First Republic when Nigeria had three strong regional governments, should be re-installed. Whether today Nigeria chooses to group the states into some form of zonal or regional arrangement or not, what should be ensured is that political groupings at all levels are given political autonomy. Nigerian nationalities, like many other pre-colonial African societies, enjoyed this in the past:

...during most of Africa's precolonial history, a significant portion of African people lived in small-scale, egalitarian societies in which government was more a matter of consensus among the entire adult population than rule by an elite few. One of the major contributions that historians of precolonial Africa have made is to demonstrate the enormous variety and complexity of precolonial African political systems and to challenge the notion that political complexity only exists in centralized states. (Shumway 2013) 


\subsection{Representative and Rotational Governance}

Representative and participatory governance was an integral aspect of Africa's pre-colonial stateless political systems. (Sesay 2014; Iweriebor, 1982) The new Nigerian constitution should enshrine provisions that would make governance more inclusive and more reflective of what Sesay (2014) portrays about Africa's pre-colonial, non-centralized societies:

Widely dispersed empires had governance systems that operated at village and town levels. Leadership was rotational rather than hereditary, with emphasis on collective decision making and implementation processes... Moreover, executive, legislative and judicial functions were diffused among various centres of power such as the village councils of elders, age grades, secret societies, etc. The system also enshrined and utilized the principle of checks and balances so that power was not concentrated in the hands of a single individual or group.

\subsection{Decisions Are Made Based on Consensus Rather Than on Majority Rule}

The history of pre-colonial African political systems indicates that consensus was favoured over majority rule. The underlying drive exhibited by the village gatherings at any level was unanimity, as also seen in the case of noncentralised societies. At every meeting, at any level, the goal was to reach a unanimous decision that would be accepted by all. Discussions and at times arguments would thus continue until a unanimous decision was reached. (Ayittey 32)

The composition of the Nigerian Senate whereby every state has 3 senators, irrespective of its size, is a good example of the practical demonstration of this principle. But there are many other dimensions to it which could be incorporated into a constitutional document aimed at restructuring Nigeria.

\subsection{Devolution of Powers and Social Cohesion}

Devolution of powers from the federal to the state governments, which the central government had resisted since the military take-over of government, is one of the fundamental problems of the Nigerian state. Nigeria should decentralize its governance systems, in line with what had worked for some of its ethnic nationalities in the past. Olowu (1994) reflects on that past:

Whether in the state or stateless societies, African precolonial political organizations had some common important attributes. First, the state was concerned with the welfare of all its citizens. Some have gone ahead to label this as communalism, but the central notion was that the welfare of every member, rather than just a few within the community, mattered. Secondly, the society was organized for political purposes on the basis of lineage: thus the lineage connected the family to the state. This ensured the state of maximum popular support but also ascertained that state sanctions can be effectively communicated. Thirdly, there was an aversion to concentrated authority. Indeed, this is the raison detre for stateless societies. A deliberate effort is made to ensure in stateless societies that each 'state' was large enough to defend itself but small enough to have internal cohesion. (Olowu 1994

\section{Conclusion}

All of the above pre-colonial African political concepts recommended for incorporation into a new "restructured" national constitution are backed up by afore-mentioned social contract concepts and by the traditional values and customs of Africa. Nigeria should seriously consider adopting and implementing them as they would help in addressing the national question. What is required is consensual restructuring founded on tenets of indigenous political representation Nigeria's over 250 ethnic and linguistic groups have traditionally been familiar with. What the country needs now is a system that frees every group from internal domination, makes it an equal stakeholder, enthrones equity and justice, and gives every ethnic stakeholder a sense of belonging.

\section{References}

i. Asike, Jude C. "Role of Philosophy in Human Development in Nigeria", UJAH, vol. 18, no. 2, 2017Abutudu, Musa. "Federalism, Political Restructuring and the Lingering National Question". Governance and Politics in Post-Military Nigeria, edited by Adejumobi S. Palgrave Macmillan, 2010. https://doi.org/10.1057

ii. Ayittey, George. Indigenous African Institutions. Transnational Publishers, 2006.

iii. Azih, Innocent. "A Background Analysis of Nigeria's Agricultural Sector". http://www.interreseaux.org/IMG/pdf_Final_Report _on_Background_Analysis_of_Nigerian_Agric_Sector_Oxfam_Novib_november_2008.pdf

iv. Fortes M. and Evans-Pritchard E. E. (eds). African Political Systems. Oxford UP, 1950. https://archive.org/stream/africanpolitical00fort/africanpolitical00fort_djvu.txt. Accessed October 7, 2019.

v. Friend, Celeste, "Social Contract Theory" https://www.iep.utm.edu/soc-cont/\#SH3b. Accessed October 10, 2019.

vi. Graham Connah's African Civilizations: An Archaeological Perspective. 2d ed. Cambridge, UK: Cambridge University Press, 2001.

vii. https://blog.euromonitor.com/changes-in-political-stability-impact-business-environments-in-emergingmarkets/ Accessed October 10, 2019.

viii. https://historians.org/about-aha-and-membership/aha-history-and-archives/gi-roundtableseries/pamphlets/em-46-our-russian-ally-(1945)/what-was-the-bolshevik-revolution Accessed October 10, 2019

ix. http://saharareporters.com/2018/02/21/transparency-international-ranks-nigeria-148th-worlds-least-corruptcountry 
x. Iweriebor, Ehiedu, E. G. "State Systems in Pre-Colonial, Colonial and Post-Colonial Nigeria: An Overview". Istituto Italiano per l'Africa e l'Oriente (IsIAO), vol. 37, no. 4, December 1982 https://www.jstor.org/stable/40759619

xi. Martin, Guy. African Political Thought. Palgrave Macmillan, 2012 https://doi.org/10.1057/9781137062055_1

xii. Mudane, Hassan. "African Political Thought in a Nutshell". Academia.edu. February 2018https://www.academia.edu/36009353/African_Political_Thought_in_a_Nutshell

xiii. Olowu, Dele. "The Nature and Character of the African State". Paper Presented for AAPAM 15th Roundtable at Banjul, Gambia, 24 - 29 January, 1994.

xiv. http://unpan1.un.org/intradoc/groups/public/documents/aapam/unpan026543.pdf

xv. Sesay, Amadu, "African Governance Systems in the Pre and Post-Independence Periods: Enduring Lessons and Opportunities for Youth in Africa". Mandela Institute for Development Studies, Johannesburg, 2014.

xvi. https://mindsafrica.org/Downloads/Youth\%20Dialogue\%202014\%20Research\%20papers/4_Prof\%20Sesay_Go vernance\%20Systems\%20in\%20Africa_Final\%20Report.pdf

xvii. Shumway, Rebecca. "Pre-Colonial Political Systems," in Thomas Spear, ed., Oxford Bibliographies in African Studies. New York: Oxford University Press, Spring 2013

xviii. Spooner, Lysander. No Treason. https://oll.libertyfund.org/titles/spooner-no-treason-no-i-1867Accessed October 8,2019
UNDP
Human
Development
Indices
and
Indicators:
2018
Statistical Updatehttp://hdr.undp.org/sites/all/themes/hdr_theme/country-notes/NGA.pdf

xx. Welson, Ekiyor. John Rawls' Political Liberalism: Implications for Nigeria's Democracy. PhD Thesis, 2011. https://ore.exeter.ac.uk/repository/bitstream/handle/10036/3213/WelsonE.pdf?sequence=1\&isAllowed=y 